\title{
Fishing Industry Perspectives on Sea-Level Rise Risk and Adaptation
}

\author{
Amanda Daria Stoltz ${ }^{1, *}$, Manoj Shivlani ${ }^{2}$ and Robert Glazer ${ }^{3}$ \\ 1 Department of Environmental Studies, University of California, Santa Cruz, CA 95064, USA \\ 2 Division of Marine Ecosystems and Society, University of Miami, Coral Gables, FL 33146, USA; \\ m.shivlani1@umiami.edu \\ 3 Florida Fish and Wildlife Conservation Commission/Fish and Wildlife Research Institute, \\ Marathon, FL 33050, USA; bob.glazer@myfwc.com \\ * Correspondence: astoltz@ucsc.edu; Tel.: +1-301-356-3496
}

Citation: Stoltz, A.D.; Shivlani, M.; Glazer, R. Fishing Industry Perspectives on Sea-Level Rise Risk and Adaptation. Water 2021, 13, 1124 https://doi.org/10.3390/w13081124

Academic Editors: Borja G. Reguero and Gary B. Griggs

Received: 26 February 2021

Accepted: 14 April 2021

Published: 20 April 2021

Publisher's Note: MDPI stays neutral with regard to jurisdictional claims in published maps and institutional affiliations.

Copyright: (c) 2021 by the authors. Licensee MDPI, Basel, Switzerland. This article is an open access article distributed under the terms and conditions of the Creative Commons Attribution (CC BY) license (https:// creativecommons.org/licenses/by/ $4.0 /)$.

\begin{abstract}
Sea-level rise, already occurring over Florida's coast, stands to generate a significant impact on the state's fishing industry and coastal communities, exposing vulnerable areas and populations to extreme events and disrupting established patterns of fishery and marine resource use. Using a semi-structured interview approach, this study evaluated fishing industry perspectives on sea-level rise risk and adaptation in three Florida coastal communities. The results showed that adaptation responses vary across industry sectors and communities and are strongly influenced by experience, community dynamics, and age. Generally, older fishers are less willing to relocate due to social factors, such as strong place attachment, compared to younger fishers, who are more likely to retreat and/or work from a less vulnerable location. These findings suggest that adaptation responses, while influenced by experience, are mediated by age, attachment to place, and worldviews, and that these factors need to be accounted for when crafting adaptation strategies across coastal communities.
\end{abstract}

Keywords: coastal management; adaptation; sea-level rise; climate change migration

\section{Introduction}

All along Florida's coasts, the disastrous effects of sea-level rise (SLR) are already taking place [1,2]. As the rate of SLR continues to increase, so will the severity of the consequences, such as shoreline erosion, saline intrusion into the water table, and the increased inundation and flooding of coastal areas [3]. Studies have shown that even gradual SLR will cause a substantially higher frequency of previously rare storm-driven water heights and an increased intensity of coastal flooding events [4-7]. The frequency of nuisance flooding in Florida has already risen with the approximate four-and-a-half-inch rise in SLR over the last 50 years, which has decreased the efficiency of many storm-water systems [8].

As coastal human populations continue to grow in Florida due to coastward migration and urbanization, more people are at risk of the hazards of SLR than ever before [9]. Florida's population has grown to 21.5 million residents, an increase of 14.2 percent over the 2010 to 2019 period [10]; an estimated 75 percent of Florida's population has in the recent few decades resided in coastal counties, which are most at risk from extreme events and SLR [11]. Analysis finds that this trend will continue, and that population growth will continue to be concentrated in storm-surge risk zones [12]. Socioeconomic drivers can have the power of mitigating SLR, in the case of sea wall construction, or exacerbating the issue, in the case of wetland destruction. Therefore, in developed areas, socioeconomic and shoreline dynamics are inextricably tied [13].

To address this ongoing threat, the state has started, albeit in fits and starts, to take meaningful action. In 2017, the State of Florida Legislature approved \$50 billion for beach renourishment to combat erosion, and in 2021, the Governor of Florida's budget proposed 
$\$ 1$ billion to address sea-level rise impacts, as part of a newly created Resilient Florida Program that, among other actions, provides funding for local resiliency programs and requires SLR projection studies for state-funded coastal construction projects commencing from July 2021 onwards [14]. Individual cities and municipalities in Florida are also funding efforts to defend the coastline from increased flooding.

Touted as the "fishing capital of the world", Florida boasts an abundance and diversity of saltwater fisheries off its 1200 mile coastline [15]. The fishing industry in coastal Florida, however, is uniquely vulnerable to the impacts of SLR because of its physical presence along often sinking coastlines and a high dependence on marine resources. Florida's coastal communities rely heavily on the fishing and/or tourism industry, and an estimated 27 percent of all recreational saltwater fishing in the US occurs in Florida [16]. The total impact of the recreational saltwater sector is estimated at $\$ 9.2$ billion, and it supports 88,501 jobs. Commercial fisheries, while not as lucrative as the recreation sector, are diverse and vary greatly from charters to commercial fishers to aquaculture operations [16]. The State of Florida issued 12,000 saltwater commercial fishing commercial licenses and 1700 wholesale dealer licenses for the 2019/20 fiscal year, which accounted for 80 million pounds in harvest and $\$ 222$ million in dockside value; Florida's commercial fishing industry generates an estimated $\$ 3.2$ billion in income and supports 76,700 jobs [17]. Charter fishing operations, which are an almost ubiquitous fixture in most Florida tourism coastal communities, generate an estimated $\$ 69.7$ million and contribute $\$ 151.2$ million to the state's economy annually [15].

Another, often underappreciated value of Florida's fishing industry is the role it plays in maintaining diverse and vibrant working waterfronts. Recognized as waterfronts that provide access to the public to navigable waters and facilities in support of vessels and vessel-based activities, including commercial fishing facilities, dock, wharfs, and marinas, and boat hauling repair facilities, among other types (ex. Florida Statute 342.201), these areas play an essential role in sustaining fishing operations and attendant fishing communities. As waterfronts become less available due to a combination of gentrification, regulatory impacts, and climate-related scarcity, fishing communities stand to lose access to areas vital to fishing operations and information exchange (such as fish houses). The locations where fishers often meet to exchange information of fishery conditions and trends, prices, and rule changes engender and foster social capital and serve as nodes in wider social networks [18] already subject to fragmentation [19-21]. Florida's vulnerable fishing communities may further disintegrate as sea level rise raises the premium on access sites least affected by/or most resistant to climate change, namely sea level rise.

However, whether the aforementioned state-driven initiatives, and related private efforts, will prove effective in holding back the sea and mitigating SLR impacts in Florida (and elsewhere) remains unclear, as predictions vary greatly; some predict widespread human migration away from coasts [22,23], while others point to emerging and maturing technical ability that will enable the successful protection of coastal areas [24,25]; organizational networks, in particular, may play a role at the local level to prioritize policies and technology [26]. There are also many important psychological aspects of adaptation, and an individual's perception of risk is paramount [27]. While experience influences individuals' concerns over climate change [28], worldviews and values may shape risk preferences, especially as these relate to policy options; thus, decision-making is likely more complex than a form of rational utility maximization at the individual level [29]. The goal of this study was to assess fishing industry perspectives of SLR risk and adaptation in the three Florida coastal communities, and the primary objective was to evaluate how community level factors, such as the types of fisheries, levels of resilience, and amount of SLR-related threat, influence views on adaptation. 


\section{Materials and Methods}

\subsection{Study Area}

The three research areas chosen for this study include Cedar Key (Levy County), Conch Key (Monroe County), and Fort Myers Beach (Lee County). The sites were identified by the authors who have local expertise in each area. These three communities represent differences in fishing practices, size, and reliance on tourism and other economic activities. The differences between each community are described further below and inform the perspectives of the fishers interviewed for this study.

Cedar Key is an isolated and historic fishing community that has survived large-scale economic and natural changes. The island is located in Levy County along Florida's central Gulf coast [30] (Figure 1). Historically, mullet fishing was the mainstay of the town and had been practiced in the area for generations. The passing of the 1995 Florida Net Ban essentially ended the mullet fishery in the area and out-of-work fishers were provided with federally funded jobs, retraining in shellfish farming [31]. The fishers who stayed and participated in this research reported success in the aquaculture industry exceeding their previous income from traditional commercial fishing. Currently, clam aquaculture and tourism (including charter fishing) are Cedar Keys' two main industries [30,32]. The success of the aquaculture industry in Cedar Keys is due to more than luck and perseverance. The island is surrounded by the Cedar Keys National Wildlife Refuge, which was established in 1929 and includes 800 acres of federally protected land [33]. These protected areas have shielded Cedar Key from the environmental impacts of coastal development that would threaten the water quality needed to grow shellfish [31].

Conch Key is a small, traditional fishing community that has not changed significantly in its infrastructure since its development in the mid-20th century. The five-acre island is located in the Middle Keys just east of the city of Marathon (Figure 2). Unlike the other two communities, Conch Key is already experiencing the effects of SLR with some areas of the island underwater at high tide. Conch Key is unique from the rest of the Florida Keys in that it is zoned as a special commercial fishing district and is one of the last communities of its kind [34]. This zoning allows Conch Key's residents to fish commercially from the island, pile lobster and crab traps in their front yards, and keep their commercial fishing boats at their docks. Conch Key consists of a mix of retirees, commercial fishers, charter captains, and retail/hotel operators. In 2018, at the time of this study, there were approximately 10 commercial fishing families and three wholesale distributors on the island. The main fisheries in Conch Key include spiny lobster, stone crab, and finfish.

Fort Myers Beach represents a new type of community, where commercial fisheries are in transition. Unlike Cedar Key and Conch Key, Fort Myers Beach is home to a larger, heavily developed fishing community that is highly dependent on tourism. Located on Estero Island in Lee County, the island is a popular tourist destination filled with charter operations, hotels, restaurants, and retail (Figure 3). The growth of the Fort Myers Beach community has been a result of the combination of fishing and tourism industries [35]. The shrimping industry boomed on the island after researchers from the University of Miami and shrimp fishers discovered the Tortugas pink shrimp fishery [36]. Other fisheries present on the island include snapper, grouper, yellowtail, and cobia. The docks are host to vertical longline vessels, crabbers, and a substantial number of charter operations that span four marinas.

\subsection{Survey and Interview Instruments}

The project team developed the survey questions for the interviews, with the assistance of fishery managers, fishery researchers, and fishing industry members unrelated to the study. The interview questions are available in the Supplementary Materials and addressed the following topics: demographics, which consisted of questions on age, race, gender, and zip code; level and type of economic investment, including job dependence, tenure, work location flexibility; work activity, such as the amount of time invested, environments targeted, and the perceived threats to business sustainability; trends and changes, including 
experience with storm events, changes in the community or environment, future plans, and predictions; and perceptions of climate change and SLR.

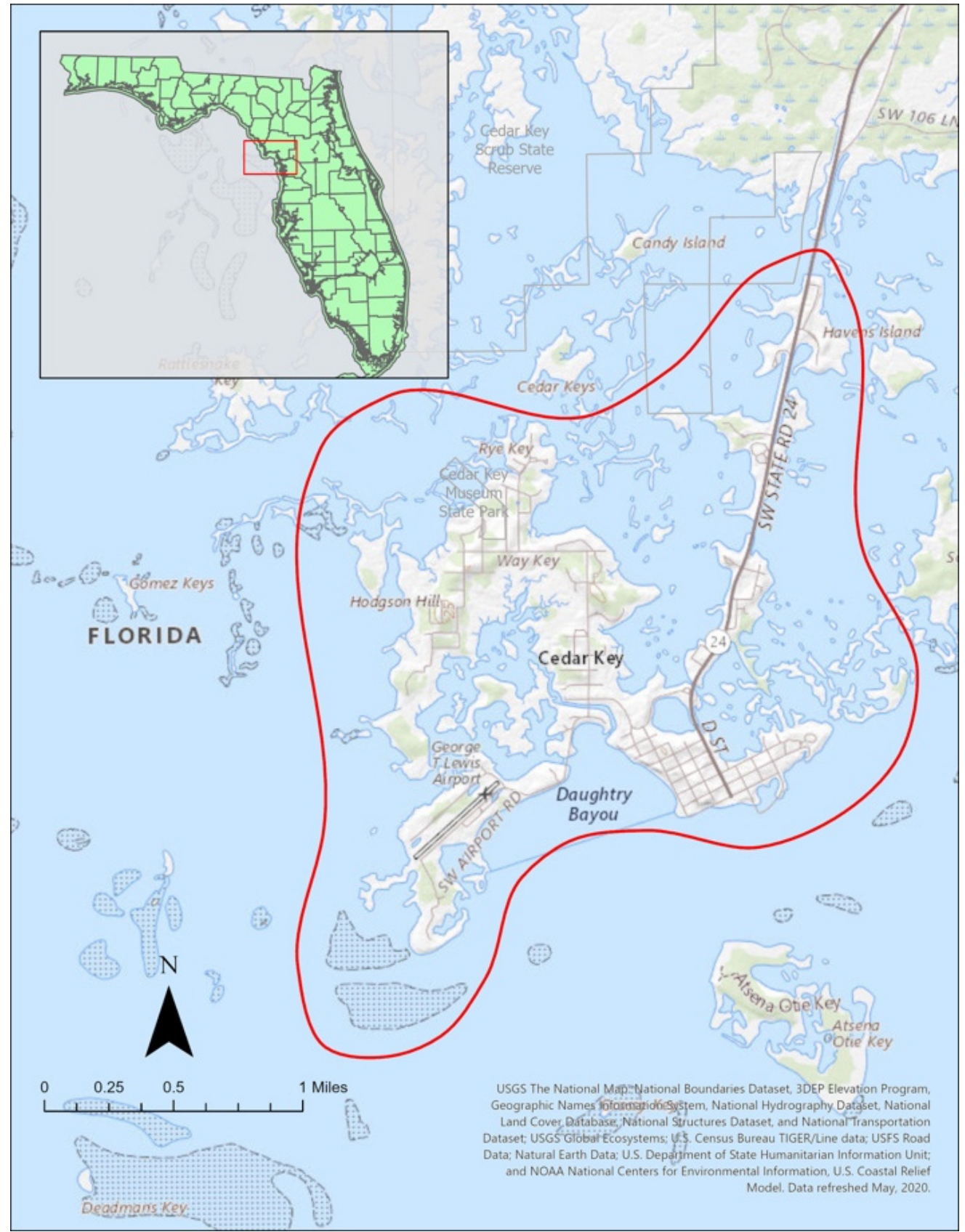

Figure 1. A map of Cedar Key with the study area outlined.

When asked about their response to SLR, participants were shown maps of how a future scenario of SLR (one meter by 2100) would occur in their area over time on an iPad (Figure 4). These images were based on elevation and divided into five-year intervals using data that depicts the trajectory of a meter of SLR by 2100 from NOAA (located at https:/ / coast.noaa.gov/slr, accessed on 20 November 2017). The map layers were presented to participants with the explanation that they depict a hypothetical situation in which the sea-level would rise one meter by 2100 with no preventative measures having taken place. It was also explained that the maps show a half inch of SLR per year, but that SLR is not linear and would instead be an uneven process and that storm events may exacerbate SLR impacts. Inundation levels were determined by the area of land 
underwater at mean higher high water. After engaging with the visual depictions of SLR in their community, participants were asked if they would stay in their community once SLR causes inundation in areas that they live and work.

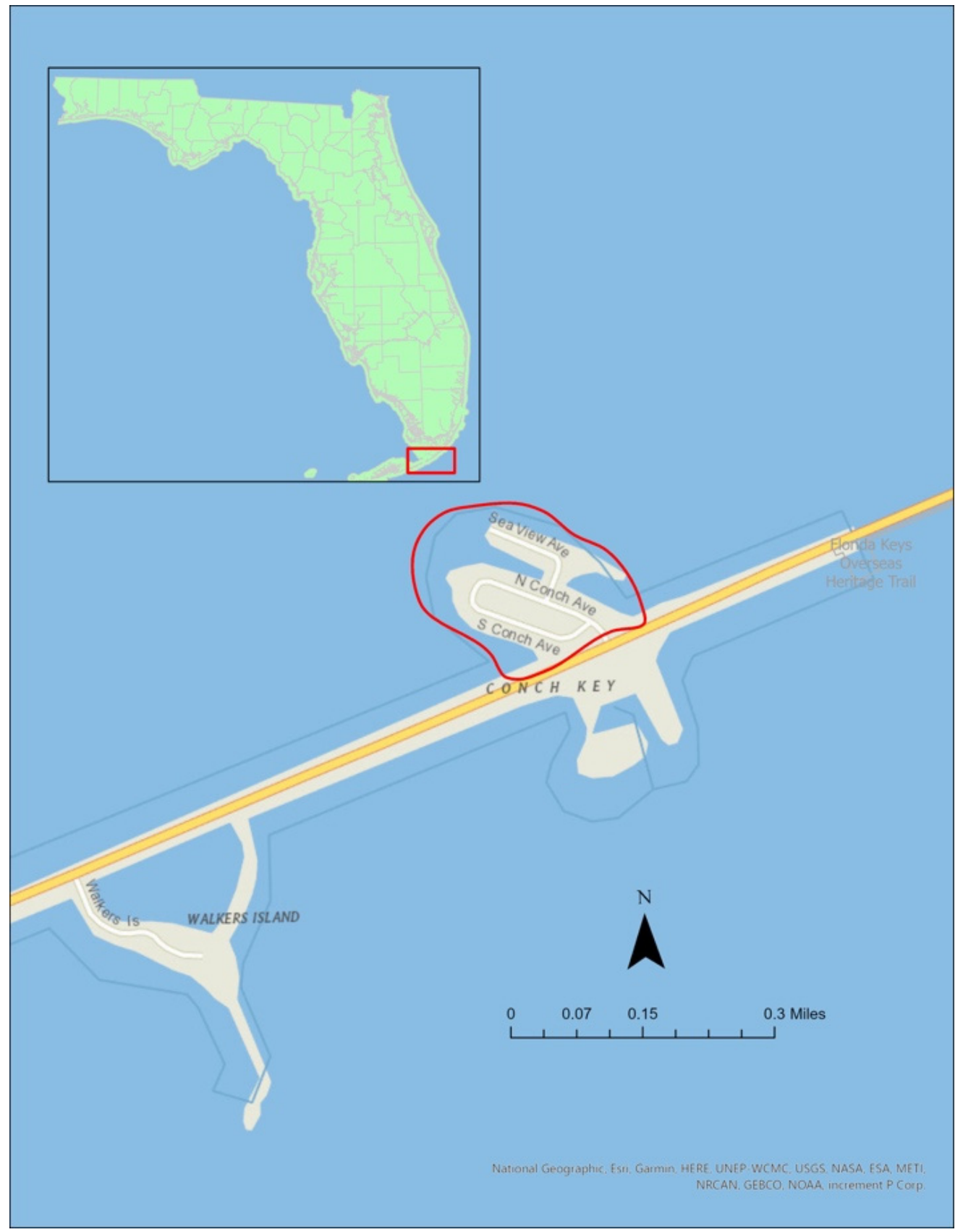

Figure 2. A map of Conch Key with the study area outlined.

\subsection{Data Collection}

This research was part of a project developed between the Florida Fish and Wildlife Conservation Commission and Marine \& Coastal Research Corp., entitled: "Projecting changes in three Florida coastal fishing communities resulting from sea level rise and the anticipated impacts to Species of Greatest Conservation Need". The data collection consisted of 44 semi-structured in-person interviews completed between December 2017 and February 2018. Each research trip was conducted after thorough background research on the fishing industry in each community, including the identification of fish houses and processing centers, marinas and boatyards, and other fishery infrastructure locations. Seafood 
wholesalers were selected through online research, as seafood wholesalers typically have a website or a page on Yelp or Facebook. The identification of commercial fishers in each region was completed by obtaining lists of active, dedicated commercial fishers from their respective fish houses, as well as spending time at docks and marinas in the morning and afternoon in order to find fishers whose contact information could not be provided by fish houses. Charter captains were identified through their contact information available online or from their marina's office. Fishing industry members without online presences were identified through snowball sampling. Interviews took place in the participant's location of choice (usually on the waterfront, fishing vessel, or office). Participants who agreed to the interview but were unable to meet in person were contacted for a phone interview.

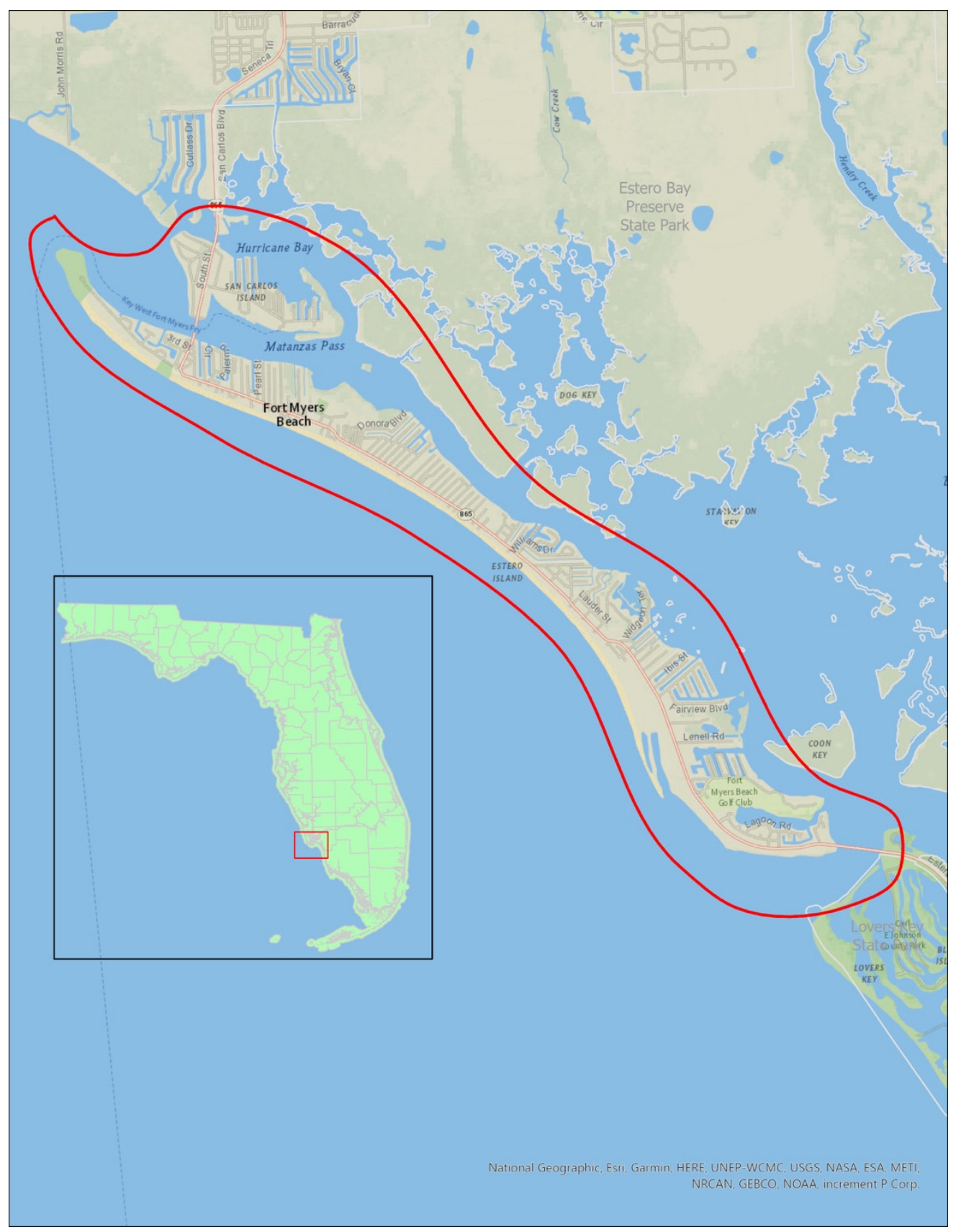

Figure 3. A map of Fort Myers Beach with the study area outlined. 


\section{Contemporary Sea-levels}
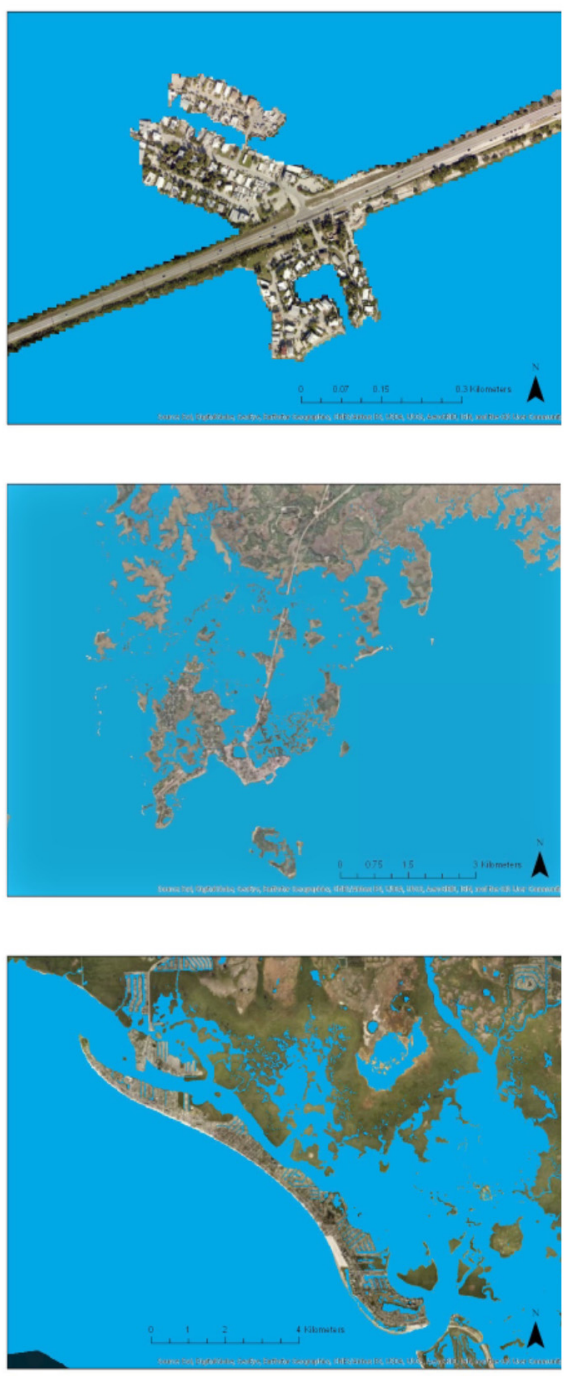

Projected Sea-level Rise in 2100
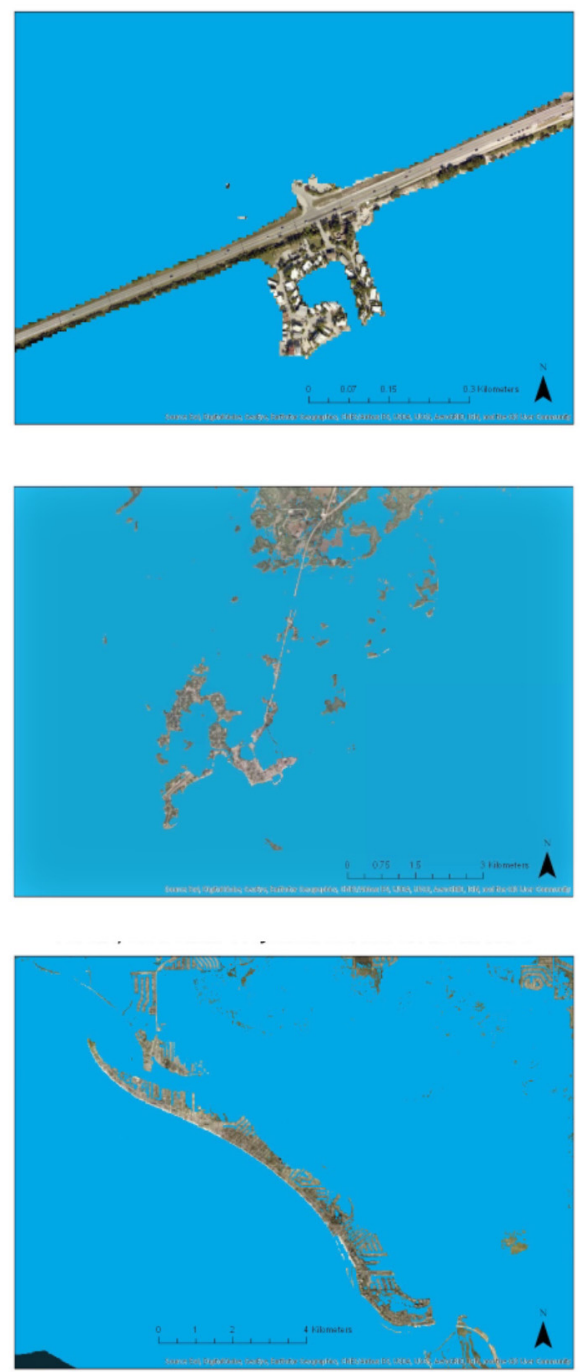

Figure 4. Examples of maps showing contemporary sea levels and the scenario of one meter of sea-level rise by 2100 in Conch Key, Cedar Key, and Fort Myers Beach.

A total of 44 participants were interviewed: 21 in Fort Myers Beach, 12 in Cedar Key, and 11 in Conch Key. These totals represent a census sample of the fishing industry, in that all fishery stakeholders had a physical presence in the community (i.e., an identifiable local business operation such as a fish house, charter fishing operation, commercial fishing vessel, etc.), self-identified as being a community member, and were either an owner or manager of a fishery business operation. Participants were assured that their names and/or the names of their business would not be used to identify them in the report.

\subsection{Data Analysis}

The data obtained in this project were collected in person using Qualtrics, a survey program, on an iPad and analyzed using Microsoft Office Excel. The interviews were audio recorded with permission from the interviewees. The data were coded using inductive coding to develop the concepts and themes discussed in this paper. The adaptation responses to the SLR scenario were coded as 'retreat', 'stay and adapt', and 'stay without adapting'. If respondents answered that they would leave their community or move inland, their answer was coded as 'retreat'. By contrast, where respondents reported that they would stay in their community despite changes caused by the SLR scenario, they 
were then asked if they would spend money defending their business or home by way of armoring, defensive measures such as sea walls, or by accommodating, building up their property. If respondents chose to stay in their community and spend money armoring or accommodating for SLR, these responses were coded as 'stay and adapt'. If respondents reported that they would stay in their community but did not agree to spend money on defense or accommodation, these responses were coded as 'stay without adapting'. Individual's views on climate change were gleaned from a qualitative analysis of the transcripts. The interview questions used to assess an individual's views on climate change included, "On a scale of one to ten how worried are you about sea-level rise?", "Based on your experience fishing, have you seen any large environmental changes in the areas that you fish in over time?", and "How would you rank climate change in terms of how it may affect your fishing operation ( 1 to 5 , where 1 is high impact and 5 is no impact)?".

\section{Results}

\subsection{Cedar Key}

Cedar Key is highly vulnerable to SLR and storm events. The maps depicting the SLR scenario of one meter by 2100 show the only road in or out of the town inundated at high tide. The maps show that the main marina will be flooded by 2050, the bridges throughout the island will become compromised by 2080 , and by 2100 , many parts of the island will be uninhabitable.

The twelve Cedar Key fishery stakeholders who participated in this project included five shellfish aquaculturists, three seafood wholesalers, and four local charter captains. Three of the shellfish aquaculture operators also owned their own seafood markets from which they sold both their own products and products purchased from smaller operations. The age of the respondents ranged between 36 and 65 years old, and 84 percent of the respondents were over 44 years old. A total of eight percent of the respondents interviewed were female. A majority of the respondents in Cedar Key (67 percent) have been in the fishing industry for more than 20 years.

The interviews revealed that the community in Cedar Key is tightly knit and has withstood several significant regulatory restrictions, disasters, and environmental changes, including the transition from net fishing to aquaculture due to the 1994 Florida Net Ban [32], the 2010 BP (British Petroleum) Deepwater Horizon oil spill, and Hurricane Hermine in 2016. Hurricane Hermine was a category 1 storm that caused substantial damage to local infrastructure. Respondents reported that the town came together to rebuild after the storm. Many of the residents of Cedar Key have lived there for multiple generations. There are many close familial ties within the commercial fishing and seafood wholesale community, and 75 percent of the commercial aquaculturists reported having family currently involved in the fishing industry. Furthermore, several respondents described a successful lobbying effort in which the locals fought to prevent the development of a golf course in the area for fear it would negatively impact the environment.

The fishing community is tightly connected through its participation in local organizations, and 88 percent of Cedar Key's commercial fishers and aquaculturists belong to organizations including the Cedar Key Oyster Association, Organized Fishermen of Florida, The Cedar Key Aquaculture Board, the National Aquaculture Association, and The Cedar Key Oyster Board. Only 25 percent of the commercial fishers and aquaculturists believed that their business is negatively impacted by competition.

When asked about climate change, only half of the respondents expressed the belief that climate change is occurring. The other half believe that any climatic changes are cyclical and not the result of anthropogenic activities. Their disbelief was due to the following factors: distrust in government, lack of physical evidence, and recent experience with cooler weather. However, denial of climate change did not prevent respondents from describing changes in their community from flooding on the roads to the increase of fish species, such as snook, which are typically found in warmer waters further south. This experience is supported by scientific studies that have shown that juvenile snook have been 
killed by episodes of cold weather near their northern limits [37]. This suggests that as the Gulf waters warm, Cedar Key fishers may see increased warm-water species surviving in areas that the species could previously not inhabit.

Of the respondents who worry that climate change will or is affecting their businesses, one noted that the annual cold front has been arriving a month later than usual, affecting the bottom line of both oystering and clamming operations as shellfish typically thrive in cooler water. Another fisher spoke of his experience with recent hurricanes in the area and his fear that hurricane strength will increase over time. Others stated that they were concerned about SLR and had seen visible impacts including the main road regularly flooding with high tides. One oyster wholesaler was particularly concerned about the impacts of erosion and explained that he has seen entire islands disappear over time and subsequently experienced the loss of oyster banks.

When shown the maps of how SLR could affect their community, a minority (eight percent) of the respondents in Cedar Key said that they would move their business inland or 'retreat' (Figure 5). Those who indicated that they would stay in Cedar Key were split between whether they would adapt to SLR (42 percent) or whether they would not adapt (50 percent) either because they do not believe SLR is going to impact them or because they do not believe they could prevent the impacts of SLR.

\section{Cedar Key Fishing Industry Responses to Sea-level Rise}

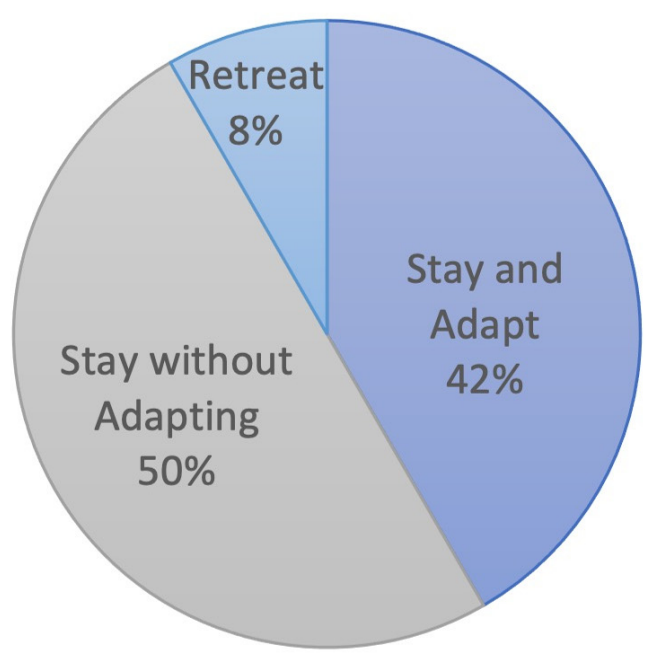

Figure 5. Cedar Key fishing industry responses to the scenario of one-meter SLR by 2100.

\subsection{Conch Key}

Conch Key is approximately three feet above sea-level and several areas of the island experience flooding during high tides including the road which connects the original island with a manmade section of the island that was created using fill. According to respondents, Hurricanes Donna (1960) and Wilma (2005) both led to island-wide overwash, and Hurricane Irma (2017) caused significant damage to the island community including substantial losses of both crab and lobster traps. The maps, which show the SLR scenario of a one-meter rise by 2100, are bleak for the island. By 2040 under the scenario, the northernmost, manmade part of the island will be underwater; by 2045, there will be significant inundation on the main island, and by 2070, the majority of Conch Key will be underwater.

The respondents from Conch Key included seafood wholesalers who also fish commercially, commercial fishers, and a charter captain. There were 11 respondents interviewed, and they ranged in age from 31 to 66 years old; 55 percent of interviewees were over 51 years of age. Over a quarter ( 27 percent) of the interviewees have been working in the 
fishing industry for 10 years or less, 18 percent of the interviewees have been working in the fishing industry for 11 to 20 years, and 55 percent have been working in the fishing industry for over 20 years. A total of 18 percent of the interviewees were women.

The interviews revealed that there is a high level of trust and cooperation among the commercial fishers in Conch Key and most of the fishers sell primarily to one fish house located on the island. The repeated interactions have likely reduced transaction costs, promoting bonding social capital as identified in other, resource-dependent communities [38,39]. However, according to a respondent who works as a seafood wholesaler, Conch Key has changed from an all-fishing community to a tourist community in the last fifteen years. In recent years, several waterfront properties have been sold to people outside of the fishing industry, and the residents of Conch Key are concerned that outsiders buying properties on Conch Key for recreational purposes may contribute to a loss of working waterfront. The effects of gentrification that affect the Florida Keys [21] are also felt in Conch Key, where business owners have had trouble finding employees that can afford housing. An interviewee who works as a lobsterman said that there has been a lot of development in Marathon, a large population center near Conch Key, which has contributed to a decrease in available workforce housing. He now struggles to find employees willing to assist with building lobster traps.

Fishery industry views on climate change in Conch Key were varied. Approximately half ( 45 percent) of the fishers in Conch Key stated that they believe that climate change is occurring and believe that it will have a large future impact on their lives. These fishers all mentioned that they have seen a rise in sea level in the past five years and that there has been a change in seasonal patterns including hotter summers.

While the remaining fishers interviewed said that they do not believe in climate change, they did acknowledge that there have been changes in the climate and sea level. These interviewees were uncomfortable with the term 'climate change' and preferred to attribute any environmental changes to natural and cyclical processes. One respondent indicated that he thought climatic change could have positive impacts as well, and that warmer waters may bring more lobster north which would benefit the lobster fishery. Only one of the interviewees, in the older age group, said that he has not seen any changes in climate, his target fishery, or the sea-level.

However, despite that the majority of the respondents acknowledging climatic changes, only 27 percent of the respondents in Conch Key thought that SLR would have a large impact on the future of their business. These respondents reported that SLR is negatively impacting their businesses now through increased flooding and that they have already begun making decisions to protect themselves from future impacts including not purchasing property on the island or building sea walls and concrete docks. Only 18 percent of respondents in Conch Key believe that SLR will have no impact on their businesses and the rest believe it will have a minimal impact.

After being shown the images depicting the SLR scenario in their community, 27 percent of Conch Key interviewees indicated that they would retreat (Figure 6). One fisher in the 'retreat' group already had plans to sell his property in the next five years before it becomes too difficult to sell due to SLR. Interestingly, one of the respondents who chose "retreat" as his response was a commercial fisherman who does not believe in climate change but who dislikes raised concrete docks which he believes have caused a decrease in the water quality of the canal next to his home that he used to swim in years ago when he was younger. He explained that if concrete docks become the norm, he will leave the island but stay in the Florida Keys.

Of the remaining respondents, 55 percent chose to 'stay and adapt' and work to defend their community from the impacts of SLR and 18 percent chose to 'stay without adapting', indicating that they are either unable to adapt due to financial or technical considerations or believe that there is nothing to be done. 


\section{Conch Key Fishing Industry Responses to Sea-level Rise}

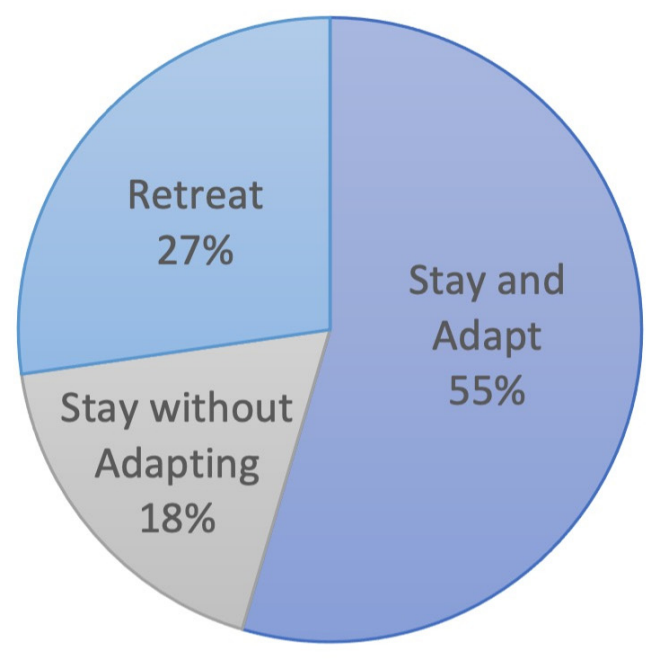

Figure 6. Conch Key fishing industry responses to the scenario of one-meter SLR by 2100.

\subsection{Fort Myers Beach}

Fort Myers Beach is less physically vulnerable to SLR than either Conch Key or Cedar Key, but in the maps depicting one meter of SLR by 2100, the beach will be underwater by 2035. By 2055, the surrounding marshes, the eastern tip of San Carlos Island (on which Fort Myers Beach is located), and the marinas will be compromised. Residential areas do not begin to flood until 2075, and by 2090, some areas of the island are completely underwater.

Twenty-one respondents were interviewed in Fort Myers Beach, including two shrimpers, 14 charter captains, two commercial fishers, two seafood wholesalers, and one charter captain who also fishes commercially on the side. Participants' ages ranged between 18 and 70 years old; 76 percent of the interviewees were 41 years or older. Fishing experience among respondents ranged between 1 and 45 years and 33 percent have been in the fishing industry for over 20 years. Ten percent of the respondents were female.

The interviews revealed that the commercial fishing industry in Fort Myers Beach has waned over the last decade. Expensive costs associated with entering the commercial fishing industry, such as permits and licenses, have kept new entries to a minimum. Shrimping has also declined in the area, which respondents attributed to regulations, including one that prevents shrimpers from harvesting their bycatch. Another trend identified by participants included depleted fish stocks and increased pollution from water discharged from Lake Okeechobee. The commercial fishers interviewed reported competition with other fishers overfishing spots and competition from seafood wholesalers outside the community.

The for-hire fishing industry in Fort Myers Beach has grown steadily over the years, alongside the growth in tourism, and a majority of the captains reported that their business income had increased. While the main activity offered on these boats is fishing, 47 percent of the captains occasionally offer other activities including eco-tours, shelling, crabbing, weddings, funerals, and snorkeling.

While charter captains were knowledgeable about the other captains and services offered at their host marina, they had little to no knowledge of charter captains in the larger Fort Myers Beach area. Only 33 percent of the captains reported belonging to recreational fishing or conservation organizations and two of the captains interviewed shared a dislike of organized fishing groups and the belief that no group would be able to create positive change. 
When asked about climate change, a majority of the commercial fishing respondents (86 percent) and 47 percent of the charter captains said that they do not believe that climate change exists. One charter captain was fervently against any discussion of climate change because he believed that $\mathrm{Al}$ Gore invented the concept as a fear mongering tactic for gaining clout, raising funds, and increasing regulation. Those who do believe in climate change identified warmer summers that have changed fish migrations and caused a decline in tourism as less northerners have come south to escape the cold. One charter captain noted, "Climate change has affected fishing and made it a lot worse because the waters are getting warmer. We used to have a definitive summer and winter and we do not have that anymore". Overall, 57 percent of Fort Myers Beach respondents did not believe SLR is occurring and did not think they would be affected in the future.

When shown the SLR scenario of a one-meter SLR by 2100, 24 percent of respondents reported that they would retreat inland or move elsewhere, 43 percent said that they would stay without adapting, and 33 percent said that they would stay and do everything in their power to adapt and defend their coastal community from SLR (Figure 7). None of the commercial fishing respondents who said that they would not adapt to SLR believe in climate change or SLR. Several respondents explained that they think adaptations are another form of governmental regulation or an "elaborate governmental fabrication". Two respondents explained that they would not need to adapt because either the area where they work will not be affected or they live on their fishing vessel. Of those who reported plans to adapt, one shrimper said, "Every place on the waterfront has bulk headed and filled. I don't see anyone running for the hills right way".

\section{Fort Myers Beach Fising Industry Responses to Sea-level Rise}

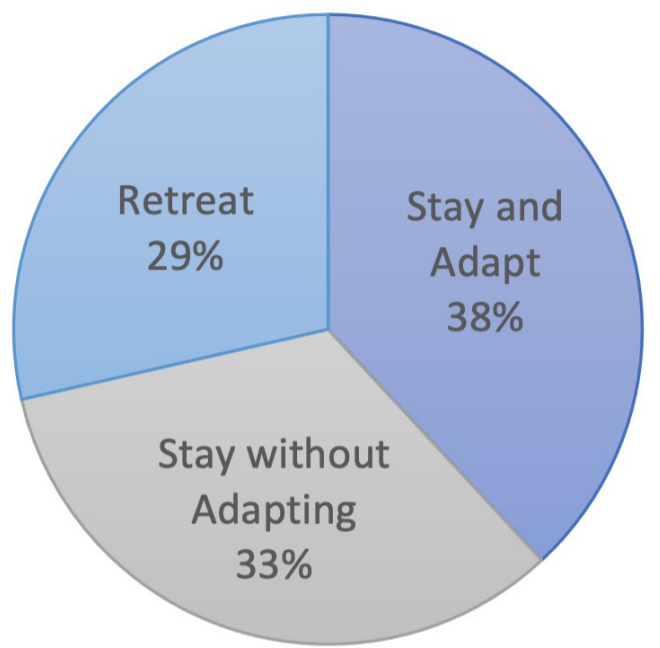

Figure 7. Fort Myers Beach fishing industry responses to the scenario of one-meter SLR by 2100.

The respondents in the retreat category included a commercial fisher who has property further inland and who plans to sell his Fort Myers Beach property before SLR makes it too difficult to sell. A charter captain in this category explained that he will stay as long as business is good but indicated that he will leave if Fort Myers Beach becomes too expensive. Interestingly, another charter captain said that he originally planned to stay in the area for the next 10 years but has been pushed to leave by the 2017 hurricane season, "I never really put much into climate change but the strongest hurricane on record kind of made me think there's something more to it. As I said, it pushed me more towards getting out of here but there are so many conflicting reports on what to believe, you know, and I'm sorry but I 
think $\mathrm{Al}$ Gore is a moron... But after seeing almost 200 mile-an-hour wind on a hurricane I mean, that's crazy. There might be something more to it than I originally thought".

\subsection{Intercommunity Analysis}

Across the three communities featured in this study, 43 percent of the interviewees reported that they would 'stay and adapt', 34 percent reported that they would 'stay without adapting', and 23 percent said that they would 'retreat' or move inland if SLR began affecting their lives negatively. Respondents in Conch Key and Fort Myers Beach were more likely to choose 'retreat' as an option than respondents in Cedar Key (Figure 8). Conch Key respondents were more likely than the other two communities to choose to 'stay and adapt' and Cedar Key respondents were the most likely to choose 'stay without adapting' as a response.

\section{Community Comparison: Stakeholder Response to Sea-level Rise}

Stay without Adapting

Stay and Adapt

Retreat

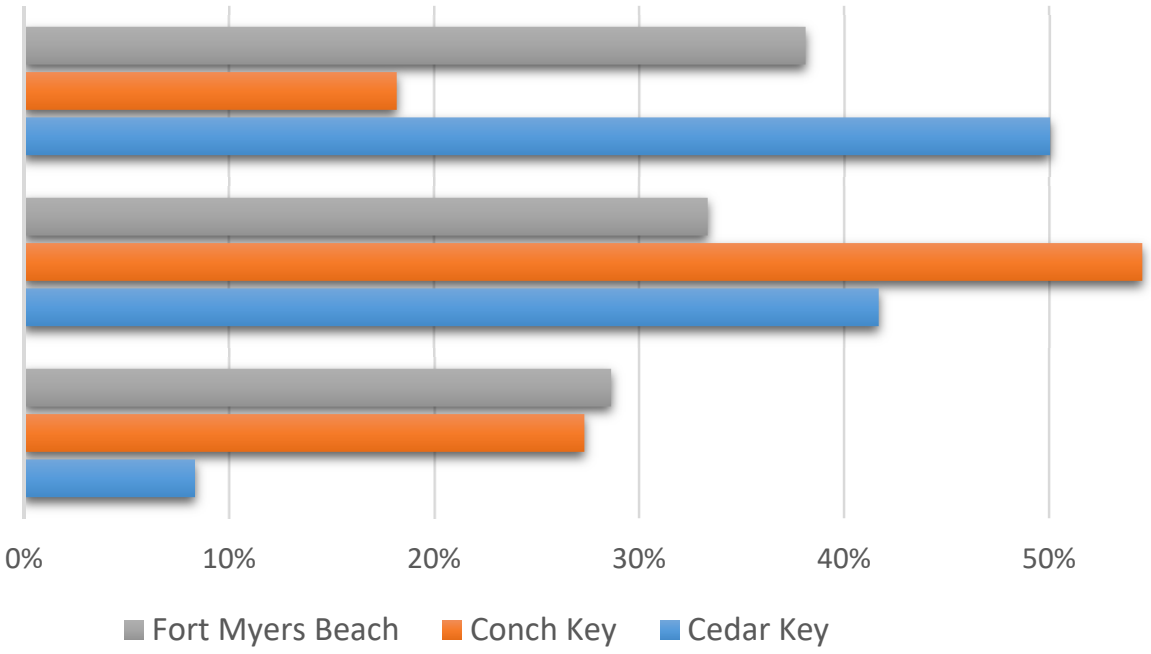

Figure 8. Fishing industry responses to the scenario of one-meter SLR by 2100 in Cedar Key, Conch Key and Fort Myers Beach.

Out of all of these factors, age was the most directly correlated with the adaptation response (Figure 9). The majority of interviewees over 60 years of age chose to 'stay without adapting' and only eight percent chose to 'retreat'. When shown the SLR scenario, respondents over 60 often remarked that they would not live to see the impacts of SLR, even when their community was already flooding during high tides.

The worldview of each respondent, i.e., whether they are a climate change believer or a climate change denier, also factored into their response to the SLR scenario. For the purpose of this study, climate change deniers are defined as those who did not acknowledge any changes in their environment over time and who were strongly against the idea of global climate change, favoring instead the idea that any environmental changes are due to cyclical and natural changes that cannot be influenced by anthropogenic factors. Climate change believers are defined in this study as those who were comfortable discussing changes in their environment such as recent changes in season length or more frequent tidal flooding that they either believe are caused by climate change or may be caused by climate change. Respondents who were climate change believers were twice as likely to choose to stay and adapt than climate change deniers (Figure 10). Climate change deniers were five times as likely to choose to stay without adapting. 


\section{Stakeholder Age and Response to Sea-level Rise}

Stay without Adapting

Stay and Adapt
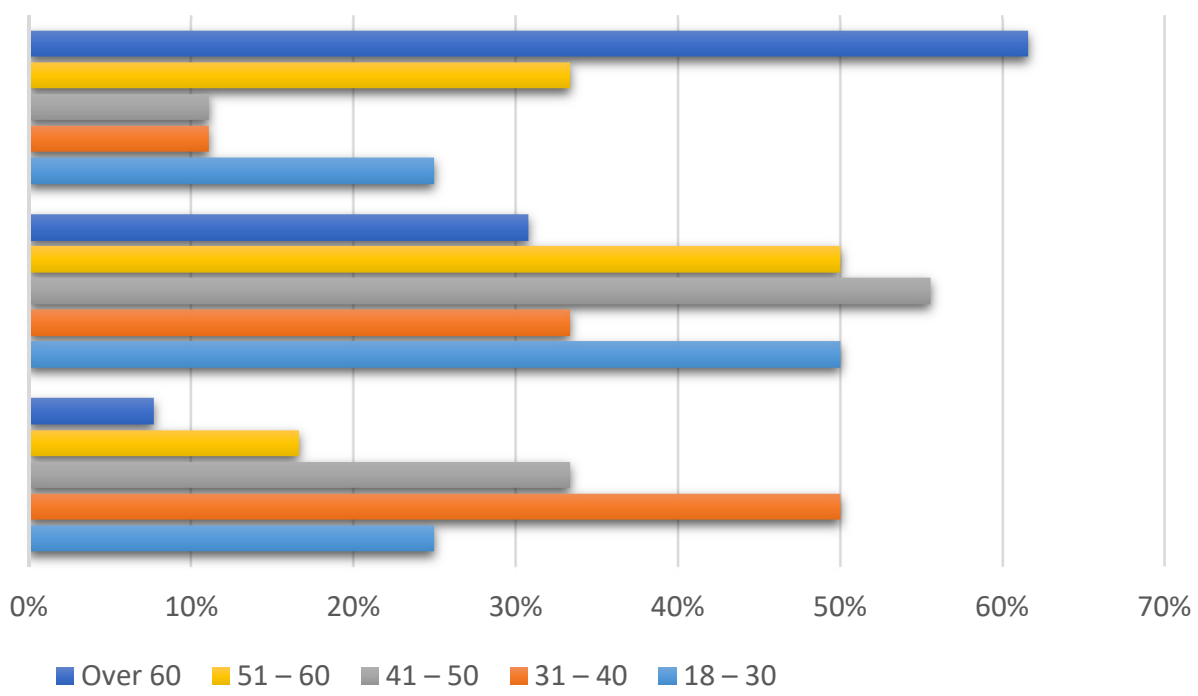

Figure 9. Fishing industry responses to the scenario of one-meter SLR by 2100 in Cedar Key, Conch Key and Fort Myers Beach categorized by age.

\section{Fishing Industry Perceptions on Climate Change and Response to Sea-level Rise}

Stay without Adapting

Stay and Adapt

Retreat

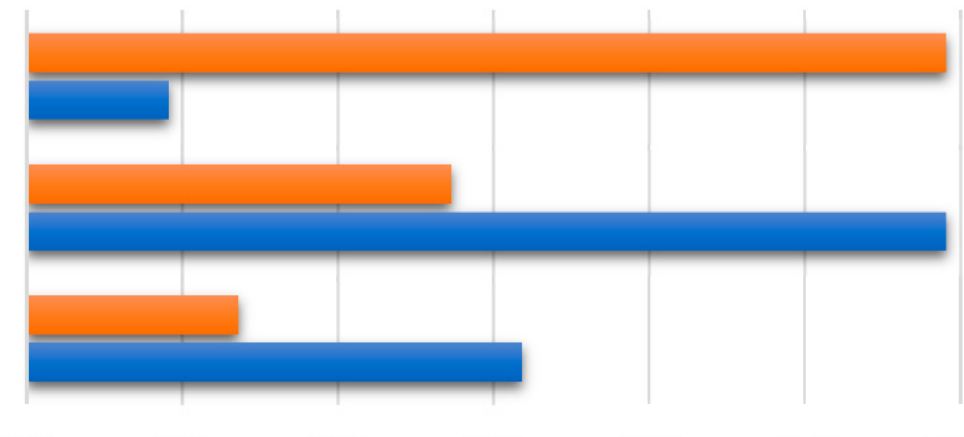

$0 \%$ $10 \% \quad 20 \% \quad 30 \%$

$40 \%$

$50 \%$

$60 \%$

$70 \%$

\section{Climate Denier c Climate Believer}

Figure 10. SLR scenario responses categorized by belief or denial in climate change.

Why individuals chose to 'stay without adapting', 'stay and adapt', or 'retreat' was based on push factors that fell into multiple categories and were coded as such. The majority of the respondents (80 percent) who chose to retreat when presented with the SLR scenario did so for economic reasons: fear of their property losing value or fear of their business losing income. While economic factors were identified in the majority of the retreat responses, the remainder of the retreat responses were due to the fear of increased storm events or the dislike of adaptation methods.

The respondents who reported that they would stay in their communities but were opposed to taking adaptive measures fit into six main categories: the belief that climate change is a government fabrication, the idea that SLR will not affect them due to their location or age, the need to focus on the issues in the present rather than the future, the inability to adapt (usually due to financial constraints), the attitude that there is no way to prevent the impacts of SLR, and the view that adaptations to SLR (e.g., sea walls, beach renourishment, and concrete docks) are bad for the environment. Anti-adaptation sentiments 
were found across the three communities and will prove to be an obstacle as Florida works to protect its coastline.

Sense of place is another key factor that determines respondents' reaction to the SLR scenario. Individuals who chose to stay and adapt did so for social reasons more so than economic. Interviewees who decided to 'stay and adapt' fit into four main categories: the idea that their investment in their property was too high to not protect, the belief that they need to protect their community from SLR impacts, the hope that their family will continue living in the area, and the need to stay in the community that their family has lived in for generations. These individuals reported a need to take care of their community as a whole, an altruistic response also shown by their reaction to previous disasters such as hurricanes. This social infrastructure appeared strong in Conch Key and Cedar Key, where fishing industry members belonged to local groups and did not worry about competition. Another sign of high social capital included reports of community members participating in efforts to protect the environment. When high social capital is present, there is a greater desire to identify with the community and defend it against SLR. Strong community identity may explain why respondents in Cedar Key were less likely to choose 'retreat' as an option even though the area is more vulnerable to SLR than Fort Myers Beach.

\section{Discussion}

The study found that, as described by Leiserowitz (2006), there exists a diversity of views in the threat posed by SLR, regardless of whether respondents believed that climate change is occurring or if climate change is mainly natural (i.e., cyclical) or anthropogenic (i.e., linear). Much of this is shaped by present circumstances, such as on Conch Key where rising sea level and storm-related overwash both demonstrate the chronic and episodic effects of climate change. In Fort Myers Beach, the diversity of views was in part shaped by past events, such as recent hurricanes, and it was also due to the majority of operations being charter fishing operations (due to the gentrification of much of the commercial waterfront over the past two decades) that rely on steady tourism for their income. Cedar Key is the most traditional of the three communities, and it-more so than Conch Key or Fort Myers Beach — has a community identity that has been shaped by the community's historical connection to its marine environment and resources. Fishing, in other words, has been a way of life for generations on Cedar Key, and even when events such as the Great Depression or the Florida Net Ban have presented challenges, the community has adapted to recover and thrive.

Studies conducted in the Gulf of Mexico region (ex., Hamilton et al., 2012) have determined that long-term economic dependency plays a pivotal role in shaping community identity and views on climate change and resource management. Residents from Gulf of Mexico states such as Louisiana, which are highly dependent on offshore oil and gas production, refineries, and other parts of the petrochemical industry, have been shown to be less willing to believe in climate change compared to residents from tourism-dependent Florida, who recently passed a constitutional amendment to prohibit offshore oil and gas drilling [40]. Within Florida, however, resource-dependent industries, such as commercial fishing, are in part shaped by the level and type of access they enjoy, based on the state and federal fishery regulatory framework. Members of these industries are thus similar to residents of oil- and gas-dependent states, as their identities are at least in part shaped by their relationship with resource extraction.

In this study, individuals' dependence on marine resources in some cases led to negative opinions of hard adaptation responses such as seawalls or raised concrete docks. This perspective was often based on fears of potential or realized damage to the marine environment. Whether individuals' views of hard adaptation solutions were legitimate environmental concerns or politically charged is challenging to ascertain. This study shows that the environmental discourse on adaptation will need to evolve, ideally alongside more development in coastal protection technology, green infrastructure, and studies showing 
the cost-effectiveness of these solutions [41]. More research is needed to examine the perspectives on different types of sea-level rise adaptation methods.

Many of the individuals in this study who were anti-adaptation were in the older generation. Across the three communities, age was a common denominator in the SLR response to stay in the area without adapting. Studies have shown that climate change belief certainty and climate change risk perception are negatively correlated with age [42-44]. The finding of age as a driver could contribute to a demographic shift in at-risk coastal communities that could increase the population's vulnerability and lower their overall resilience.

Participant age, worldview, and community identity all factored into individuals response to the potential SLR scenario. These findings support coastal planning efforts by illustrating why coastal planning must be conducted in a way that is sensitive to place-based cultural norms and potential ideological or worldview issues such as climate change skepticism [45]. Determining the factors behind how fishing industry members will react to sea-level rise provides managers with an important baseline for creating community-informed adaptation plans [46,47]. In other words, fostering consensus in these communities about the risks of sea-level rise may equally or more important than raising awareness.

\section{Conclusions}

The study findings demonstrate that factors influencing stakeholder views on SLR are complex and interrelated, and that communities that may appear superficially homogeneous, whether those are in Florida or the rest of the globe, are in fact diverse and thus may not respond to a 'one-size-fits-all' adaptation approach. Resilience therefore can best be increased if the unique combination of factors influencing recovery and adaptation are identified, assessed, and included in an adaptation strategy or framework, whether these factors are measured in terms of socio-ecological indicators denoting resistance to ecological and anthropogenic stressors [48] or instances (cases) of where communities have rebounded from extreme events or chronic climate shifts. While the study does not predict the future for fishing industries in coastal communities in Florida or in areas undergoing similar changes elsewhere in the world, the results do show that age, sense of place, and worldview all factor into stakeholders' decisions to stay, adapt, or retreat when faced with rising seas and an uncertain future.

Supplementary Materials: The following are available online at https:/ /www.mdpi.com/article/10 .3390/w13081124/s1, Florida Fishing Communities \& SLR Survey.

Author Contributions: Conceptualization, A.D.S., M.S. and R.G.; methodology, A.D.S., M.S. and R.G.; formal analysis, A.D.S.; investigation, A.D.S.; resources, M.S. and R.G.; data curation, A.D.S.; writing — original draft preparation, A.D.S., M.S. and R.G.; writing—review and editing, A.D.S., M.S. and R.G.; visualization, A.D.S. and M.S.; supervision, M.S. and R.G.; project administration A.D.S., M.S. and R.G.; funding acquisition, M.S. and R.G. All authors have read and agreed to the published version of the manuscript.

Funding: This research was funded by the Florida Fish and Wildlife Conservation Commission for a grant entitled: "Projecting changes in three Florida coastal fishing communities resulting from sea level rise and the anticipated impacts to Species of Greatest Conservation Need".

Institutional Review Board Statement: The study was conducted according to the guidelines of the Declaration of Helsinki, and approved by the Institutional Review Board of the University of Miami (protocol code 20170775, approved 24 October 2017).

Informed Consent Statement: Informed consent was obtained from all subjects involved in the study.

Data Availability Statement: Data available on request from the corresponding author. The data are not publicly available to protect the privacy of the subjects. 
Acknowledgments: We would like to acknowledge Maria Estevanez for her mentorship, support, and the creation of the maps used in this paper. Thanks also go to Kenneth Broad for his guidance during this project, and to the University of Miami and the Florida Fish and Wildlife Conservation Commission for providing the needed resources. We thank Nicholas Castillo and Samantha Dowdell who both assisted with crafting the survey questions. Finally, we owe immense gratitude to the incredible fishers of the Florida coast who trusted us with their stories.

Conflicts of Interest: The authors declare no conflict of interest.

\section{References}

1. Sweet, W.V.; Park, J. From the extreme to the mean: Acceleration and tipping points of coastal inundation from sea level rise. Earth's Futur. 2014, 2, 579-600. [CrossRef]

2. McAlpine, S.A.; Porter, J.R. Estimating Recent Local Impacts of Sea-Level Rise on Current Real-Estate Losses: A Housing Market Case Study in Miami-Dade, Florida. Popul. Res. Policy Rev. 2018, 37, 871-895. [CrossRef]

3. Walton, T.L. Projected sea level rise in Florida. Ocean Eng. 2007, 34, 1832-1840. [CrossRef]

4. Knutson, T.R.; McBride, J.L.; Chan, J.; Emanuel, K.; Holland, G.; Landsea, C.; Held, I.; Kossin, J.P.; Srivastava, A.K.; Sugi, M. Tropical Cyclones and Climate Change. Nat. Geosci. 2010, 3, 157-163. [CrossRef]

5. Nicholls, R.J.; Wong, P.P.; Burkett, V.; Codignotto, J.; Hay, J.; Woodroffe, C.D.; Abuodha, P.; Arblaster, J.; Brown, B.; Forbes, D.; et al. Coastal systems and low-lying areas. In Climate Change 2007: Impacts, Adaptation and Vulnerability. Contribution of Working Group II to the Fourth Assessment Report of the Intergovernmental Panel on Climate Change; Cambridge University Press: Cambridge, UK, 2007; pp. 315-356.

6. Tebaldi, C.; Strauss, B.H.; Zervas, C. Modelling sea level rise impacts on storm surges along US coasts. Environ. Res. Lett. 2012, 7, 014032. [CrossRef]

7. Taherkhani, M.; Vitousek, S.; Barnard, P.L.; Frazer, N.; Anderson, T.R.; Fletcher, C.H. Sea-level rise exponentially increases coastal flood frequency. Sci. Rep. 2020, 10,1-17. [CrossRef]

8. Ghanbari, M.; Arabi, M.; Obeysekera, J. Chronic and Acute Coastal Flood Risks to Assets and Communities in Southeast Florida. J. Water Resour. Plan. Manag. 2020, 146, 04020049. [CrossRef]

9. Nicholls, R.J.; Small, C. Improved estimates of coastal population and exposure to hazards released. Eos 2002, 83, 301. [CrossRef]

10. U.S. Census Bureau QuickFacts: Florida. Available online: https://www.census.gov/quickfacts/fact/table/FL/POP060210 (accessed on 21 February 2021).

11. Wilson, S.; Fischetti, T. Coastline Population Trends in the United States 1960 to 2008. Available online: https: / /www.census.gov / library/publications/2010/demo/p25-1139.html (accessed on 20 February 2021).

12. Frazier, T.G.; Wood, N.; Yarnal, B.; Bauer, D.H. Influence of potential sea level rise on societal vulnerability to hurricane storm-surge hazards, Sarasota County, Florida. Appl. Geogr. 2010, 30, 490-505. [CrossRef]

13. Lazarus, E.D.; Murray, A.B. An integrated hypothesis for regional patterns of shoreline change along the Northern North Carolina Outer Banks, USA. Mar. Geol. 2011, 281, 85-90. [CrossRef]

14. Governor Ron DeSantis Announces His "Florida Leads" Budget Proposal for FY 2021-2022. Available online: https://www. flgov.com/2021/01/28/governor-ron-desantis-announces-his-florida-leads-budget-proposal-for-fy-2021-2022 (accessed on 15 February 2021).

15. Asadi, M. Evaluating the Economic Impact of Recreational Charter Fishing in Florida Using Hedonic Price and Economic Impact Analysis. FIU Electron. Theses Diss. 2016. Available online: https:/ /digitalcommons.fiu.edu/cgi/viewcontent.cgi?article=3807 \&context=etd (accessed on 20 February 2021). [CrossRef]

16. Hanson, C.; Sauls, B. Status of Recreational Saltwater Fishing in Florida: Characterization of License Sales, Participation, and Fishing Effort. In The Angler in the Environment: Social, Economic, Biological, and Ethical Dimensions; Beard, D., Arlinghaus, R., Sutton, S., Eds.; American Fisheries Society: Bethesda, MD, USA, 2011; ISBN 978-1-934874-24-0.

17. The Economic Impacts of Saltwater Fishing in Florida. Available online: http://myfwc.com/conservation/value/saltwaterfishing/ (accessed on 21 February 2021).

18. Ropicki, A.J.; Larkin, S.L. Social Network Analysis of Price Dispersion in Fishing Quota Lease Markets. Mar. Resour. Econ. 2014, 29, 157-176. [CrossRef]

19. Yu, H. Fishing-Dependent Communities on the Gulf Coast of Florida: Their Iden. Available online: https://scholarcommons.usf. edu/etd/1394/ (accessed on 21 February 2021).

20. Colburn, L.L.; Jepson, M.; Weng, C.; Seara, T.; Weiss, J.; Hare, J.A. Indicators of climate change and social vulnerability in fishing dependent communities along the Eastern and Gulf Coasts of the United States. Mar. Policy 2016, 74, 323-333. [CrossRef]

21. Shivlani, M. Impact of Non-Fishery Factors on the Performance of Commercial Fisheries: Case Study of the Florida Keys, 1950-2007. Ph.D. Thesis, Florida International University, Miami, FL, USA, 2014.

22. Nicholls, R. Planning for the Impacts of Sea Level Rise. Oceanography 2011, 24, 144-157. [CrossRef]

23. Bates, D.C. Environmental Refugees? Classifying Human Migrations Caused by Environmental Change. Popul. Environ. 2002, 23, 465-477. [CrossRef]

24. Anthoff, D.; Hahn, R. Government failure and market failure: On the inefficiency of environmental and energy policy. Oxf. Rev. Econ. Policy 2010, 26, 197-224. [CrossRef] 
25. Hinkel, J.; Lincke, D.; Vafeidis, A.T.; Perrette, M.; Nicholls, R.J.; Tol, R.S.J.; Marzeion, B.; Fettweis, X.; Ionescu, C.; Levermann, A. Coastal flood damage and adaptation costs under 21st century sea-level rise. Proc. Natl. Acad. Sci. USA 2014, 111, $3292-3297$. [CrossRef] [PubMed]

26. Kauneckis, D.; Martin, R. Patterns of Adaptation Response by Coastal Communities to Climate Risks. Coast. Manag. 2020, 48, 257-274. [CrossRef]

27. Grothmann, T.; Patt, A. Adaptive capacity and human cognition: The process of individual adaptation to climate change. Glob. Environ. Chang. 2005, 15, 199-213. [CrossRef]

28. Seara, T.; Clay, P.M.; Colburn, L.L. Perceived adaptive capacity and natural disasters: A fisheries case study. Glob. Environ. Chang. 2016, 38, 49-57. [CrossRef]

29. Leiserowitz, A. Climate Change Risk Perception and Policy Preferences: The Role of Affect, Imagery, and Values. Clim. Chang. 2006, 77, 45-72. [CrossRef]

30. McCarthy, K. Cedar Key, Florida: A History (Brief History); The History Press: Charleston, SC, USA, 2007.

31. Smith, S.; Jacob, S.; Jepson, M.; Israel, G. After the Florida Net Ban: The Impacts on Commercial Fishing Families. Soc. Nat. Resour. 2003, 16, 39-59. [CrossRef]

32. Colson, S.; Sturmer, L.N. One Shining Moment Known as Clamelot: The Cedar Key Story. Available online: https://www. sciencebase.gov/catalog/item/50541a37e4b097cd4fcfdcf5 (accessed on 25 February 2021).

33. U.S. Fish \& Wildlife Service (FWS). Home-Cedar Keys-U.S. Fish and Wildlife Service. Available online: https://www.fws. gov/refuge/cedar_keys/ (accessed on 25 February 2021).

34. Monroe County Land Development Code. Available online: https://www.monroecounty-fl.gov/DocumentCenter/View/1125 9/LDC-Final-Adopted-Version---with-ORD-030-2016-change (accessed on 20 February 2021).

35. Brown, B. A Short History of Fort Myers Beach: Estero and San Carlos Islands; Florida; Estero Island Publishers: Fort Myers Beach, FL, USA, 1965.

36. Idyll, C.P. The Commercial Shrimp Industry of Florida. Commer. Fish. Rev. 1950, 12. Available online: https://spo.nmfs.noaa. gov/sites/default/files/pdf-content/mfr1232.pdf (accessed on 20 February 2021).

37. Shenker, J.M.; Hronszky, I.; Nelson, G.L. Effects of Climate Change on Fishery Species in Florida. In Proceedings of the AIP Conference Proceedings, Melbourne, Florida, 29-30 July 2009; pp. 39-47.

38. Grafton, R.Q. Social capital and fisheries governance. Ocean Coast. Manag. 2005, 48, 753-766. [CrossRef]

39. Pretty, J. Social Capital and the Collective Management of Resources. Science 2003, 302, 1912-1914. [CrossRef] [PubMed]

40. Hamilton, J.D. Oil Prices, Exhaustible Resources, and Economic Growth. In Handbook on Energy and Climate Change; NBER Working Paper Series; Edward Elgar Publishing: Cheltenham, UK, 2012; No. w17759.

41. Reguero, B.G.; Beck, M.W.; Bresch, D.N.; Calil, J.; Meliane, I. Comparing the cost effectiveness of nature-based and coastal adaptation: A case study from the Gulf Coast of the United States. PLoS ONE 2018, 13, e0192132. [CrossRef]

42. Rothermich, K.; Johnson, E.K.; Griffith, R.M.; Beingolea, M.M. The influence of personality traits on attitudes towards climate change-An exploratory study. Pers. Individ. Differ. 2021, 168, 110304. [CrossRef]

43. Cain, B.E.; Gerber, E.R.; Hui, I. Getting bipartisan support for sea level rise adaptation policies. Ocean Coast. Manag. 2020, 197, 105298. [CrossRef]

44. Poortinga, W.; Spence, A.; Whitmarsh, L.; Capstick, S.; Pidgeon, N.F. Uncertain climate: An investigation into public scepticism about anthropogenic climate change. Glob. Environ. Chang. 2011, 21, 1015-1024. [CrossRef]

45. Saleem Khan, A.; Sabuj Kumar, M.; Sudhir Chella, R.; Devdyuti, B. BASIEC: A Coastal Climate Service Framework for CommunityBased Adaptation to Rising Sea-Levels. In Handbook of Climate Services; Climate Change Management; Leal Filho, W., Jacob, D., Eds.; Springer International Publishing: Cham, Switzerland, 2020; pp. 11-31. ISBN 978-3-030-36875-3.

46. Gray, S.; Gagnon, A.; O’Dwyer, B.; O’Mahony, C.; Muir, D.; Devoy, R.; Falaleeva, M.; Gault, J. Are coastal managers detecting the problem? Assessing stakeholder perception of climate vulnerability using Fuzzy Cognitive Mapping. Ocean Coast. Manag. 2014, 94, 74-89. [CrossRef]

47. Stephens, S.H.; Delorme, D.E.; Hagen, S.C. Coastal Stakeholders' Perceptions of Sea Level Rise Adaptation Planning in the Northern Gulf of Mexico. Environ. Manag. 2020, 66, 407-418. [CrossRef] [PubMed]

48. Karnauskas, M.; Schirripa, M.J.; Kelble, C.R.; Cook, G.S.; Craig, J.K. Ecosystem Status Report for the Gulf of Mexico; NOAA Technical Memorandum NMFS-SEFSC-653; U.S. Department of Commerce: Miami, FL, USA, 2013; 58p. 